\title{
Diagnostic Simulation of Water Age in Small Lake of Bosten Lake
}

\author{
Ying Liu ${ }^{1,2,3,4} \mathbb{( D}$, Ruisen Zhong ${ }^{1,2,3,4, *}$, Anming Bao ${ }^{1,2,3,4}$ and Tie Liu 1,2,3,4 (D) \\ 1 State Key Laboratory of Desert and Oasis Ecology, Xinjiang Institute of Ecology and Geography, \\ Chinese Academy of Sciences, Urumqi 830011, China; lyhello@yeah.net (Y.L.); baoam@ms.xjb.ac.cn (A.B.); \\ liutie@ms.xjb.ac.cn (T.L.) \\ 2 Research Center for Ecology and Environment of Central Asia, Chinese Academy of Sciences, \\ Urumqi 830011, China \\ 3 Key Laboratory of GIS \& RS Application Xinjiang Uygur Autonomous Region, Urumqi 830011, China \\ 4 College of Resources and Environment, University of Chinese Academy of Sciences, Beijing 100049, China \\ * Correspondence: zhongrs@ms.xjb.ac.cn; Tel.: +86-991-7823168
}

Citation: Liu, Y.; Zhong, R.; Bao, A.; Liu, T. Diagnostic Simulation of Water Age in Small Lake of Bosten Lake. Water 2021, 13, 1996. https:// doi.org/10.3390/w13151996

Academic Editors: Frédéric Huneau and Francesco Gallerano

Received: 13 May 2021

Accepted: 18 July 2021

Published: 21 July 2021

Publisher's Note: MDPI stays neutral with regard to jurisdictional claims in published maps and institutional affiliations.

Copyright: (c) 2021 by the authors. Licensee MDPI, Basel, Switzerland This article is an open access article distributed under the terms and conditions of the Creative Commons Attribution (CC BY) license (https:// creativecommons.org/licenses/by/ $4.0 /)$

\begin{abstract}
Concerns have increased regarding water quality deterioration in arid land water. Water age is a useful indicator of the susceptibility of water bodies to water quality deterioration and is helpful for knowing the basic mechanisms governing the transport of materials through water bodies. In the current study, the spatial distributions of water age in the small lake of Bosten Lake (hereinafter referred to as small lake) were investigated with a two-dimensional hydrodynamic model built on the basis of the Environmental Fluid Dynamics Code (EFDC) model. In particular, the influences of different water flow periods, farmland drainages, and wind directions on water age distributions in the small lake were investigated. The modeled water age in the small lake has high spatial variability. The water age is maximum at the northeastern part and minimum at the center of the small lake. The water age in the small lake is lower during wet periods and gets larger for dry periods. After five years' simulation, the average water age in the whole small lake system was 594, 684, and 794 days under wet, normal, and dry periods. Increasing the hydraulic connectivity of the small lake can reduce its water age by opening its ecological gate inflow and Ahongkou gate outflow. This is the more favorable hydraulic conditions promoting water exchange in most regions of the small lake and can be used in hydraulic engineering to improve its water age. The farmland drainages should be controlled around the small lake. The mean water age of the whole small lake under the northwestern wind is lower than that under the southwestern wind. The simulated results provide important information for comprehending the water exchange efficiency, help in discovery of areas of the small lake most likely to experience water quality degradation, and can be used to design the engineering projects to improve or protect the water environment.
\end{abstract}

Keywords: transport timescale; hydrodynamic model; water age; EFDC; small lake of Bosten Lake; Kaidu River

\section{Introduction}

Affected by inappropriate human activities and climate change, most freshwater bodies go through water quality deterioration to some extent [1-3]. Water quality deterioration will imperil potable water supplies, public health, and ecosystem sustainability. Previously, in arid regions, more attention was paid to water quantity problems. Now, many water quality problems have appeared. The water quality problems of a water body have been widely linked to the water exchange capability of the system.

The water exchange process, one of the hydrodynamic characteristics, generally plays a vital role in the transport and redistribution of nutrients, salt, suspended sediments, pollutants, biological species, etc. [4,5]. To quantify this process, the concept of water transport timescales has been proposed [6-10]. The timescales are key physical attributes 
of a water body that relate to how long water molecules and their contained dissolved and suspended materials are in that water body, owing to different transportation mechanisms (i.e., advection and diffusion). They have many advantages to quantify the chemical, biological, and physical processes in a given water body, and have been extensively applied for obtaining water circulation and mixing, and studying biochemical processes rates in lakes, estuaries, and oceans [11-13]. They are important indicators for the quantitative assessment of water exchange and renewal capacity of water bodies $[6,7,14]$. Estimation of transport timescales is very crucial for water environment management intentions because they are closely associated with the ecosystem health and water quality of the various water systems in the world [4,15].

A variety of indicators have been proposed to evaluate water transport timescales [6-8,12,15-21]. Among these indicators, water age is a helpful hydrodynamic indicator in quantifying temporally and spatially the processes of water exchange and material transport in rivers, lakes/reservoirs, estuaries, coasts, and oceans with wide water exchange triggered by different flow rates, wind, tide, and density structure or human regulations, and was successfully applied in big shallow lakes having limited water movement $[7,12,21-30]$. Water age is a complement to water residence time. Water age shows the time a water molecule has taken after entering a water body from one of the boundaries; in other words, it is the time needed for a water molecule to transport from the inlets of a water body to a specific position inside the system $[6,7,12,14,15,18,20-24,31]$. The residence time of a water molecule is defined as the time required for the water molecule to get to the outlet $[7,14]$ and, hence, can be considered as the rest of the lifetime of a water molecule within a water body [7]. Compared to bulk timescales, the age of water is one of the most frequently used, more informative local transport timescales which exhibit more detailed, spatial distribution information on a system's water renewal capacity [20]. Water age has the advantage of continuing changing spatially and temporally throughout the simulation period and computational domain under different hydraulic and meteorological conditions $[7,22]$. The areas featured by high water age values are hence "stagnant zones" related to limited circulation, whereas the areas featured by low water age values are zones associated with high circulation. This kind of feature is helpful for management intentions, for it helps the recognition of the regions in a water body that, owing to the low circulation capacity, are very apt to water quality degradation [32]. Some studies have employed water age as a hydrodynamic indicator to predict water quality (e.g., nutrients) and algae (chlorophyll-a) $[4,5]$. Knowledge of water age can significantly aid in the assessment of the environmental status and the sustainable management of water bodies.

The spatial variations of water age of the small lake of Bosten Lake (hereinafter referred to as small lake), a typical lake in the arid regions of Northwest China, where water resource is scarce and water quality problem reports still remain largely unknown. The objective of the present research is to study the spatial distributions of water age in the small lake, through a numerical hydrodynamic model and the effects of different quantities and positions of inflow and outflow, wind directions, and agriculture drainages on it to represent the water exchange capability and the water quality situation of the small lake under different situations. The scenarios include when it: (1) is under wet periods; (2) is under normal periods; (3) is under dry periods; compared to (3), (4) is set to transfer the outflow of the big lake of Bosten lake (hereinafter referred to as big lake) into the small lake through the ecological gate between the small lake and big lake, and increase the outflow of the small lake through Dawutizha gate which is equal to the transferring inflow; compared to (4), (5) is set to increase the outflow of the small lake through Ahongkou gate; compared to (3), and (6) is under northwestern wind while (3) is under southwestern wind. The findings of this study will indicate the water renewal capability in different regions of the small lake, and should help understand the material exchange, transport process, and environmental issues and provide the local authority and decisionmakers with helpful information to improve environment and aquaculture management. 


\section{Methods}

\subsection{Study Area}

Bosten Lake $\left(41^{\circ} 44^{\prime} \sim 42^{\circ} 14^{\prime} \mathrm{N}, 86^{\circ} 20^{\prime} \sim 87^{\circ} 26^{\prime}\right.$ E) was previously the largest Chinese inland freshwater lake and is the largest lake in Xinjiang, situated in southern Xinjiang, the arid and semi-arid area in the northwest of China. It is divided into a big lake and a small lake by dam in 1983 [33]. The big lake is the main part of the lake. The small lake in the southwest of the big lake is a wetland rich in reeds, called Xiaohu reed district, where reed marsh interlaces with waterways and 16 open waters [34] (Figure 1). Historically, the two lakes were connected. The highway built between the big lake and small lake in 1997 once blocked their water connection, which caused the water quality deterioration. In the spring of 1998, more than 80 tons of fish died due to water pollution in the small lake; therefore, artificial dikes were built in the road to reconnect the big lake and small lake, and there are culvert gates on the dike for the two-way connection of ecological water [35].

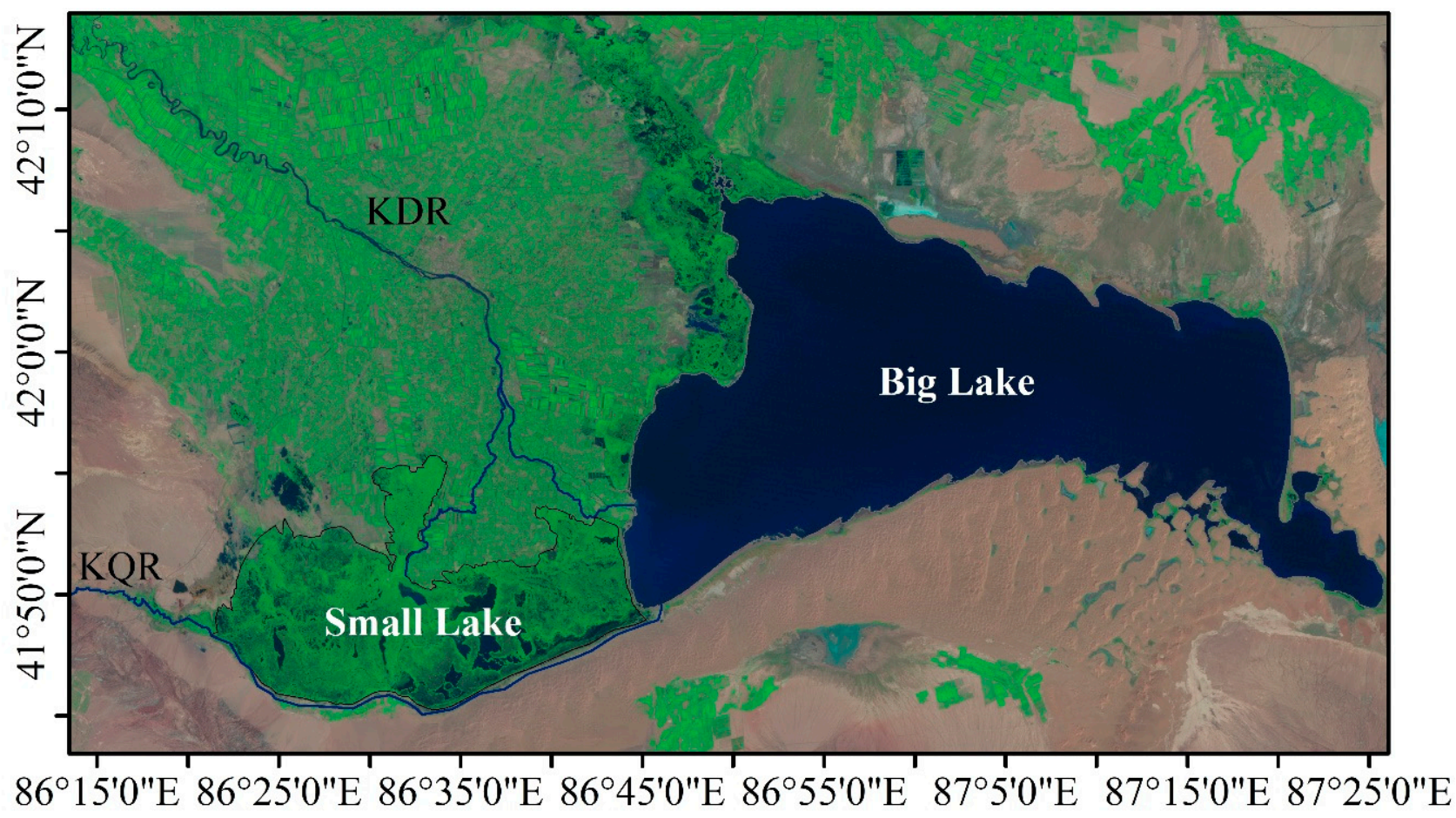

Figure 1. The schematic map of the Bosten Lake (Landsat bands 7, 4, and 2 pseudo-color composed image) showing its big lake and small lake (where KDR and KQR represent Kaidu River and Kongque River).

The climate here is characterized as dry, with cold winters and hot summers. The average annual air temperature is $8.4{ }^{\circ} \mathrm{C}$ [36]. Winds majorly blow from the southwest, exhibiting prominent influence of the westerlies in summer.

When water level is $1048 \mathrm{~m}$ a.m.s.l., the big lake has a water surface area of $1160 \mathrm{~km}^{2}$, mean and maximum water depth of $8.1 \mathrm{~m}$ and $15 \mathrm{~m}$, respectively, and storage capacity of $8.41 \times 10^{9} \mathrm{~m}^{3}$ [37]. The area of the small lake area is $363.94 \mathrm{~km}^{2}$ [38]. The depth of open waters of the small lake is 2-6 $\mathrm{m}$ [39].

Kaidu River is the primary perennial branch stream of the Bosten Lake, accounting for $\sim 83.4 \%$ of its total inflow [40]. It is separated into east branch and west branch at the downstream Baolangsumu water diversion junction which regulates the water amount flowing into the small lake and big lake, and the water division ratio of the east and west branch of Kaidu River is 6:4 [41]. The big lake maintained natural outflow conditions historically until an artificial pumping station was built in 1983. Then, through a channel, the big lake water has been pumped out to the Kongque River (Figure 1). Under the current situation, the inlet is at the middle north side of the small lake, the inflow of the west 
branch of Kaidu River, and the outlet is at the western side of the small lake, the Dawutizha gate (DWTZ) (Figure 2). The water of the small lake flows to Kongque River through the DWTZ. The Ahongkou gate (AHK) and ecological gate (EG) was not opened.

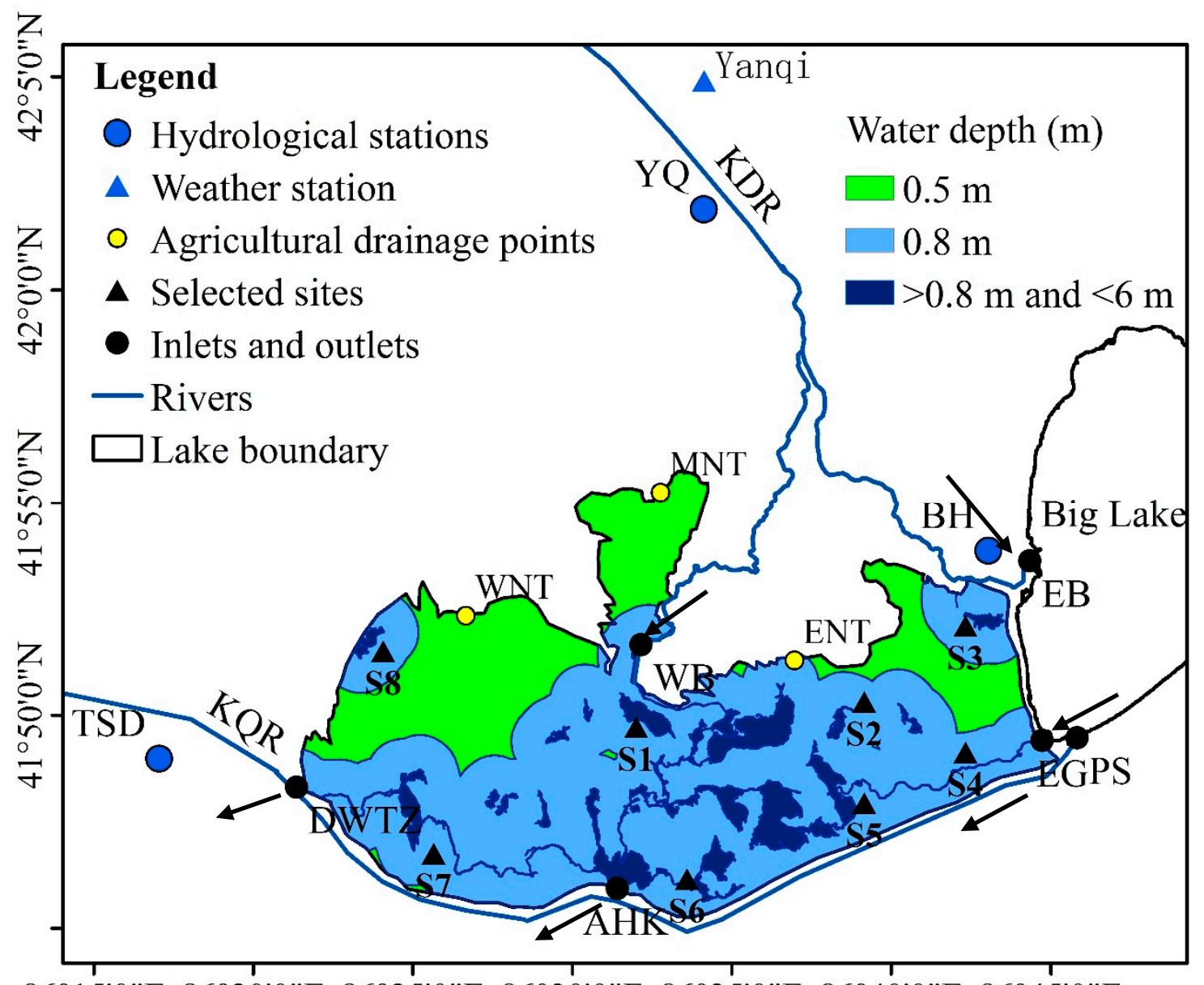

$86^{\circ} 15^{\prime} 0^{\prime \prime} \mathrm{E} 86^{\circ} 20^{\prime} 0^{\prime \prime} \mathrm{E} 86^{\circ} 25^{\prime} 0^{\prime \prime} \mathrm{E} 86^{\circ} 30^{\prime} 0^{\prime \prime} \mathrm{E} 86^{\circ} 35^{\prime} 0^{\prime \prime} \mathrm{E} 86^{\circ} 40^{\prime} 0^{\prime \prime} \mathrm{E} 86^{\circ} 45^{\prime} 0^{\prime \prime} \mathrm{E}$

Figure 2. The schematic map of the small lake and its water depth (where black solid triangles show the location of the selected sites for presenting spatial change of water age; KDR, KQR, TSD, YQ, and BH stand for the Kaidu River, the Kongque River, the Tashidian, Yanqi, and Bohu stations, respectively; black sold circles represent the inlets and outlets of the small lake and big lake, in which WB and EB represent the inlets of the west branch and the east branch of Kaidu River and EG, DWTZ, PS, and AHK represent the ecological gate, Dawutizha gate, pumping station, and Ahongkou gate; the yellow solid circles show the agriculture drainage points, in which WNT, MNT, and ENT represent the west, middle, and east agriculture drainage point, respectively; the black arrows show the schematic flow direction of the inlets and outlets; the bathymetry was designed through field investigation data used for the EFDC (Environmental Fluid Dynamics Code) hydrodynamic modeling).

The 90th percentile of high water level/flow, mean water level/flow, and 20th percentile of low water level/flow are representative of wet, mean, and dry hydrologic conditions [12]. Under the wet, normal, and dry periods, the water level of Bosten Lake is $1047.5,1046.18$, and $1045 \mathrm{~m}$; the inflow of the big lake is $92.08,77.60$, and $64.98 \mathrm{~m}^{3} / \mathrm{s}$; and the outflow of the big lake is 90,50 , and $20 \mathrm{~m}^{3} / \mathrm{s}$, respectively [42]. The annual potential evaporation rate approaches $1800-2000 \mathrm{~mm}$, and the annual precipitation is merely $68.2 \mathrm{~mm}$, chiefly falling in summer [36].

Bosten Lake is at the beginning of the Kongque River and the terminal of the Kaidu River. It plays a significant role in controlling floods from the Kaidu River and providing water for the Basin of Kongque River and the lower reaches of the Tarim River watershed. It plays an important role in fish and wild reed production, and wildlife breeding. Its water and wetland resources are extremely important natural and economic resources for 
Xinjiang, and have irreplaceable ecological environmental functions, such as controlling pollution, eliminating poisons, purifying water quality, controlling soil erosion, maintaining biodiversity, and regulating river runoff and local climate [39,43-46]. However, since the 1960s, due to large-scale industrial and agricultural development activities, changes in the natural environment, and the rapid increase in the number of people in the Yanqi Basin, coupled with the unreasonable development and utilization of water resources, the ecological environment of Bosten Lake and its lakeside wetlands has deteriorated sharply, such as wetland degradation, increased lake water salinity, and increased eutrophication [34,44,47-49], which seriously affects the stability and ecological service functions of the watershed ecosystem [50]. The increasingly severe water environment problems of Bosten Lake have attracted people's attention, and the governance of Bosten Lake has been included in the national 21st century "lake governance plan" agenda and Xinjiang's "1311" environmental protection action plan [51].

Here, the small lake was focused on for its important ecological function as the lakeside wetlands of the Bosten Lake. Water quality improvement of the small lake has drawn many researchers' attention for decades [33,49]; however, the water quality distribution of the small lake has been little reported. Here, eight sites (S1, S2, S3, S4, S5, S6, S7, and S8) were selected to show the spatial change of water environment in the small lake (Figure 2).

\subsection{Hydrodynamic Model Description and Configuration}

The Environmental Fluid Dynamics Code (EFDC), initially made by Hamrick (1996) [52], was applied here to simulate the hydrodynamic processes of the small lake. The EFDC model is a program package that is used to simulate one, two, and three-dimensional flow, transportation, and biological and chemical processes in the surface water system $[53,54]$. The model has been employed widely to simulate the flow circulation, sediment transport, thermal stratification, water quality, and eutrophication processes in various aquatic systems including lakes, reservoirs, rivers, estuaries, coastal ocean regions, and wetlands, supporting environmental management and evaluation [54-59]. The EFDC model has four key modules that include a hydrodynamic module, a sediment transportation module, a water quality module, and a toxic materials module [54-58]. It solves free-surface, vertically hydrostatic, and turbulent-averaged equations of fluid movement for a density-variable fluid. The EFDC is driven by atmospheric conditions (e.g., wind shear, surface heat flux), inflow/outflows, manual withdrawal, and irrigation return flows. The hydrodynamic model includes continuity equation, Reynolds momentum equations, state equation, and conservation equations for salinity and temperature, and the Mellor-Yamada level 2.5 turbulence closure scheme $[60,61]$ is applied to estimate the vertical turbulent diffusivity and viscosity.

The model uses boundary-fitted orthogonal curvilinear horizontal coordinates and vertical sigma transformation to describe the physical features of a water body. An orthogonal curvilinear grid model can precisely describe the complicated lake boundaries and has the superiority of computing efficiency over unstructured grid models. Furthermore, it combines finite-difference and finite-volume techniques to guarantee mass conservation, which probably causes problems in finite element methods. The code is a public domain and open-source system. Further information of the EFDC model, such as the governing equations for the hydrodynamic model and substance conservation model, and the numerical solution technologies, is available in literature [54,57,62].

The hydrodynamic model was constructed previously with the EFDC for the Bosten Lake (the big lake) and had been well-calibrated with the available observations for temperature, salinity, and water level [63]. Since the small lake is next to the big lake and it is small, it is assumed that the big lake EFDC model can be used for the small lake with its own input conditions. Here, the EFDC was used for simulating diagnostically the water age in the small lake. The EFDC has been used in many studies to simulate water age [27,28]. The bathymetry of the small lake was designed on the basis of the field investigation (Figure 2). The depth of the open water regions was the observed data. The $1 \mathrm{~km}$ buffer of the open water regions was set to the depth of $0.8 \mathrm{~m}$ and the rest region was set to 
the depth of $0.5 \mathrm{~m}$. In the horizontal direction, a boundary-fitted orthogonal curvilinear mesh was built containing the region of model domain, which contains 278 active cells having an identical mesh grid size of $1100 \times 1100 \mathrm{~m}$ (Figure 3). In the vertical direction, one layer sigma coordinate was applied to simulate the topography of the small lake bottom. For the hydrodynamic model, the parameters associated with the Mellor and Yamada turbulence model [60] were assigned to the values, similar to the ones applied in other hydrodynamic models, for example the Estuary, Coastal, and Ocean Model and the Princeton Ocean Model [64]. The dimensionless parameter of viscosity was assigned to a constant value of 0.1 in the Smagorinsky (1963) formula [65] for the horizontal turbulence model [66]. The bottom roughness coefficient $\mathrm{Z} 0$ was assigned to a representative value of $0.01 \mathrm{~m}[54,64]$. To consider the fluctuations of water level in the small lake, a varying water surface boundary was employed in the model by setting a threshold value for the water depth to determine the dry $(0.05 \mathrm{~m})$ and wet $(0.1 \mathrm{~m})$ grid elements, which means the grid elements are not involved in calculations when their water depths are lower than $0.05 \mathrm{~m}$ and are involved in calculations when their water depths are deeper than $0.1 \mathrm{~m}$ [67]. The model was run with a time step of $87.805 \mathrm{~s}$ to meet the computation demand and the needs of the stability criterion of Courant-Friedrichs-Lewy condition. The initial water velocity was set to zero. For the whole simulation period, the atmospheric conditions of atmosphere pressure, relative humidity, air temperature, rainfall rate, evaporation rate, fractional cloud cover, and solar short-wave radiation were assigned as constants, the mean value of the 2005 data of Yanqi weather station which is $4.5 \mathrm{~km}$ away from the small lake (Figure 2). The simulation time period was 5 years. The results present in this paper are all after five years' simulation. Water age is related with the simulation time period. The longer the simulation time period, the larger the water age for some stagnant zones. Through many times' simulation, a five-year simulation period was determined as it is long enough to reflect the water age distribution of the small lake.

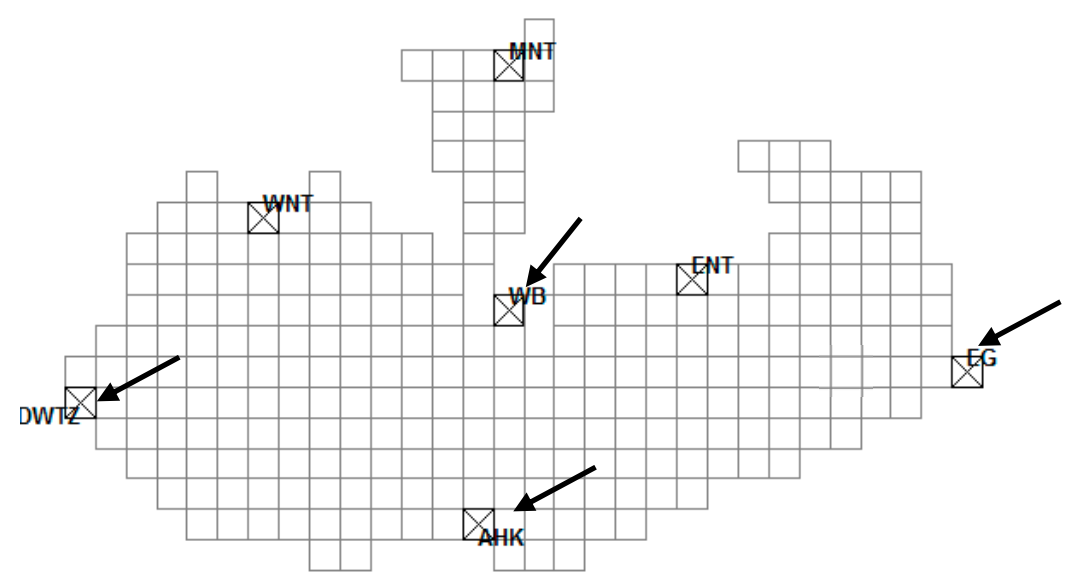

Figure 3. The computational grids and input and output boundary in the model (where the grids with a cross are the inlet and outlet cells, in which WB represents the inlets of the west branch of Kaidu River; DWTZ and AHK represent Dawutizha gate, and Ahongkou gate; WNT, MNT, and ENT represent the west, middle, and east agriculture drainage points, respectively; the black arrows show the schematic flow direction of the inlets and outlets).

\subsection{Transport Timescale Calculation}

The age of a water molecule was calculated through modeling a tracer and age concentration in the EFDC hydrodynamic model. On the basis of the constituent-oriented age and residence time theory (CART), the water age can be obtained through solving two advection-diffusion equations [22,24]. Regardless of the extra source and sink 
parts, the tracer concentration, $C$, and the age concentration, $\alpha$, can be calculated by Equations (1) and (2), respectively.

$$
\begin{gathered}
\frac{\partial C(t, x, y, z)}{\partial \mathrm{t}}+\nabla(\vec{u} C(t, x, y, z)-K \nabla C(t, x, y, z))=0 \\
\frac{\partial \alpha(t, x, y, z)}{\partial \mathrm{t}}+\nabla(\vec{u} \alpha(t, x, y, z)-K \nabla \alpha(t, x, y, z))=C(t, x, y, z)
\end{gathered}
$$

where $u$ is the velocity vector, $t$ is the time, $K$ is the diffusivity tensor, and $x, y, z$ is the location vector. The average water age can be computed as below:

$$
\mathrm{a}(t, x, y, z)=\frac{\alpha(t, x, y, z)}{C(t, x, y, z)}
$$

Equations (1)-(3) were employed to compute the age of a water molecule through the EFDC model with determined initial and boundary conditions. The initial conditions for the tracer and its age concentration were assigned to zero in every cell of the model domain. If the transport processes as a result of advection and diffusion are disregarded (such as no motion in the least in the aquatic system), the water age of the small lake will be 1 day after the first day simulation, and 2 days after the second day, and so forth. If the specific cell is flushed day by day during the simulation period, the water age could not possibly be more than 1 day. Water age is constantly modeled for the computational cell each time step. It can, afterwards, be calculated discontinuously or averaged over spatial and temporal scales of interest.

\subsection{Scenario Definitions}

Six numerical simulation scenarios (Table 1) were carried out and compared to study the influences of different inflows and outflows, agriculture drainages, and wind directions (WD). For all simulations, the configurations and other parameter assignments of the model mentioned previously were kept the same as scenario E1. The scenarios' specific conditions were as follows: E1, E2, and E3 represent the situation of the wet, normal and dry periods, with high, middle, and low water level, inflow, and outflow, respectively. Under dry periods, compared to E3, E4 and E5 have set more $20 \mathrm{~m}^{3} / \mathrm{s}$ inflow through ecological gate flowing into the small lake which is equal to the outflow of the pumping station of the big lake and $20 \mathrm{~m}^{3} / \mathrm{s}$ outflow of the small lake through Ahongkou gate (E4) and Dawutizha gate (E5). E6 (northwestern wind, NW), compared to E3 (southwestern wind, SW), only has wind direction different (Table 2). In addition, farmland drainages have been added to the six scenarios to observe the influence of farmland drainages in the water age of the small lake. The agriculture drainages are represented by three points on the north part of the small lake (Figure 2). Adding farmland drainages is similar to increasing inflow, but with more tracer concentration. The farmland drainages were assigned to $4,0.6$, and $0.4 \mathrm{~m}^{3} / \mathrm{s}$ at the west, middle, and east agriculture drainage points (WNT, MNT, and ENT) (Figure 2) respectively, which were obtained from the annual agriculture drainages data of the region. E1-N, E2-N, E3-N, E4-N, E5-N, and E6-N represent six scenarios without considering the farmland drainages. E1-F, E2-F, E3-F, E4-F, E5-F, and E6-F represent six scenarios considering the farmland drainages. According to field data, the trace concentration of salt at the inlet of the west branch of Kaidu River (WB) was $0.24 \mathrm{mg} / \mathrm{L}$, at ecological gate (EG) between the big lake and small lake it was $1 \mathrm{mg} / \mathrm{L}$, at Dawutizha gate (DWTZ) it was $0.82 \mathrm{mg} / \mathrm{L}$, at Ahongkou gate (AHK) it was $0.82 \mathrm{mg} / \mathrm{L}$, and at all the farmland drainages points it was $1.38 \mathrm{mg} / \mathrm{L}$. The inflow of the small lake was determined according to the inflow of the big lake and the water division ratio of the east and west branch of Kaidu River. The designed outflow of Dawutizha gate of the small lake under the wet, normal, and dry periods was based on the outflow of 90,50 , and $20 \mathrm{~m}^{3} / \mathrm{s}$ from the east-west pumping station of the big lake under the wet, normal, and dry periods, and the assumption that the ratio of the outflow from the small lake and the big lake was equal to the water division 
ratio of 6:4 for the east and west branch of Kaidu River, the inflow of the big lake and small lake, so the outflow from Dawutizhan gate under the wet, normal, and dry periods were $60,33.3$, and $13.3 \mathrm{~m}^{3} / \mathrm{s}$. The wind speed was set to $3.5 \mathrm{~m} / \mathrm{s}$, which is the mean wind speed of the region.

Table 1. The implemented scenarios and their conditions.

\begin{tabular}{cc}
\hline Scenarios & Conditions \\
\hline E1 & The wet periods \\
\hline E2 & The normal periods \\
\hline E3 & The dry periods \\
\hline E4 & Same as E3, open Ecological gate (EG) inflow and Ahongkou gate (AHK) outflow \\
\hline E5 & Same as E3, open Ecological gate (EG) inflow and Dawutizha gate (DWTZ) outflow \\
\hline E6 & Same as E3, under different wind direction (WD) \\
\hline
\end{tabular}

Table 2. The specific conditions of different scenarios.

\begin{tabular}{ccccccc}
\hline Scenarios & Water Level (m) & WB $\left(\mathbf{m}^{3} / \mathbf{s}\right)$ & EG $\left(\mathbf{m}^{3} / \mathbf{s}\right)$ & $\begin{array}{c}\text { AHK } \\
\left(\mathbf{m}^{3} / \mathbf{s}\right)\end{array}$ & $\begin{array}{c}\text { DWTZ } \\
\left(\mathbf{m}^{3} / \mathbf{s}\right)\end{array}$ & WD \\
\hline E1 & 1047.5 & 61.4 & 0.0 & 0.0 & 60.0 & SW \\
\hline E2 & 1046.2 & 51.8 & 0.0 & 0.0 & 33.3 & SW \\
\hline E3 & 1045.0 & 43.3 & 0.0 & 0.0 & 13.3 & SW \\
\hline E4 & 1045.0 & 43.3 & 20 & 20 & 13.3 & SW \\
\hline E5 & 1045.0 & 43.3 & 20 & 0.0 & 33.3 & SW \\
\hline E6 & 1045.0 & 43.3 & 0.0 & 0.0 & 13.3 & NW \\
\hline
\end{tabular}

\section{Results}

\subsection{Spatial Variation of the Water Age}

The simulation indicates significant spatial variability of the water age in the small lake under different inflow and outflow conditions (Figure 4, Table 3). The water age is higher at the northwestern corner, and small in the middle of the small lake due to high water exchange (Figure 4). The water age of different sites is various (Figure 2, Tables 3 and 4). Among the selected sites, the water age is minimum, 6 days, at S1 under wet periods, and maximum, 1584 days, at S3 under dry periods (Figure 2, Table 3). Under scenario E1 without considering farmland drainages, the lowest value of water age, 6 days, is at S1, in the middle of the small lake, and the highest value of the water age, 1445 days, is at S3, in the northeastern corner of the small lake (Figure 2, Table 3). The change of water age of different sites varies depending on the position of the sites and the quantities of the inflow and outflow.

\subsection{Influences of the Wet, Normal, and Dry Periods}

Through model analysis, it is found that the water age in the small lake after five years' simulation is lower in most areas under wet periods. After five years' simulation, the average water age of the whole small lake is 594 days under the wet periods with inflow and outflow of 61.4 and $60 \mathrm{~m}^{3} / \mathrm{s}, 684$ days under the normal periods with inflow and outflow of 51.8 and $33.3 \mathrm{~m}^{3} / \mathrm{s}$, and 794 days under the dry periods with inflow and outflow of 43.3 and $13.3 \mathrm{~m}^{3} / \mathrm{s}$ (Table 5). The minimum mean water age of the whole small lake is 550 days among the different scenarios (Table 5). The distribution of water age shows that it spent fewer than 200,600, and 800 days for the salt discharged at the inlets to be moved to the outlets under wet, normal, and dry periods, respectively (Figure 4). Since the outflow shows corresponding changes in accordance with the inflow of the small lake, and the quantities of the inflow and outflow during wet periods are more than those during 
dry periods, therefore, the water age of the small lake is lower during wet periods and larger during dry periods.
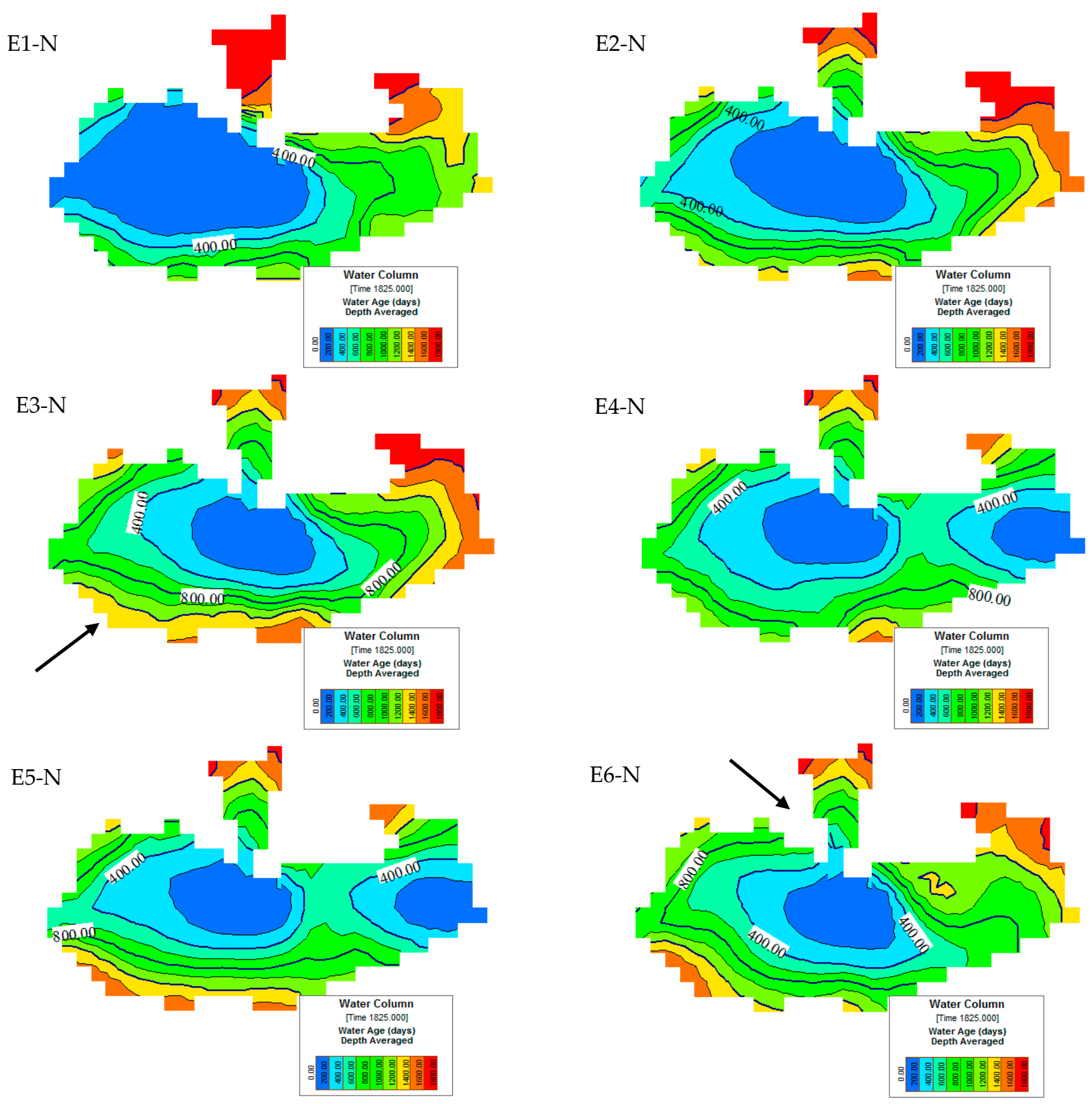

Figure 4. The water age distribution in the small lake after 5 years' simulation under different scenarios (without considering farmland drainages, and the black arrows represent the schematic wind direction in the two comparing scenarios E3 and E6). 
Table 3. The water age (day) of the sites 1-8 (S1, S2, S3, S4, S5, S6, S7, and S8 in Figure 2) after 5 years' simulation for the six scenarios without farmland drainages (E1-N, E2-N, E3-N, E4-N, E5-N, and E6-N).

\begin{tabular}{ccccccccc}
\hline & S1 & S2 & S3 & S4 & S5 & S6 & S7 & S8 \\
\hline E1-N & 6 & 780 & 1445 & 1040 & 1117 & 823 & 356 & 288 \\
\hline E2-N & 21 & 902 & 1519 & 1139 & 744 & 1219 & 771 & 831 \\
\hline E3-N & 35 & 894 & 1472 & 1190 & 749 & 1296 & 1098 & 1081 \\
\hline E4-N & 28 & 290 & 714 & 51 & 574 & 1341 & 641 & 1041 \\
\hline E5-N & 29 & 290 & 715 & 51 & 573 & 1185 & 1135 & 925 \\
\hline E6-N & 31 & 1070 & 1584 & 834 & 579 & 855 & 1246 & 1065 \\
\hline
\end{tabular}

Table 4. The water age (day) of the sites $1-8$ (S1, S2, S3, S4, S5, S6, S7, and S8 in Figure 4) after 5 years' simulation for the six scenarios with farmland drainages (E1-F, E2-F, E3-F, E4-F, E5-F, and E6-F).

\begin{tabular}{ccccccccc}
\hline & S1 & S2 & S3 & S4 & S5 & S6 & S7 & S8 \\
\hline E1-F & 10 & 999 & 1648 & 875 & 715 & 561 & 381 & 252 \\
\hline E2-F & 25 & 1064 & 1607 & 951 & 591 & 798 & 819 & 485 \\
\hline E3-F & 46 & 941 & 1480 & 1215 & 773 & 1291 & 1159 & 771 \\
\hline E4-F & 34 & 340 & 783 & 61 & 687 & 1445 & 725 & 720 \\
\hline E5-F & 36 & 339 & 783 & 61 & 692 & 1289 & 1195 & 653 \\
\hline E6-F & 36 & 1113 & 1594 & 898 & 570 & 934 & 1323 & 600 \\
\hline
\end{tabular}

Table 5. The average water age of the whole small lake after 5 years' simulation for the six scenarios.

\begin{tabular}{lcccccc}
\hline & E1 & E2 & E3 & E4 & E5 & E6 \\
\hline Without farmland drainages & 594 & 684 & 794 & 550 & 598 & 757 \\
\hline With farmland drainages & 568 & 670 & 801 & 579 & 626 & 773 \\
\hline
\end{tabular}

The water age of all the sites under wet periods is almost lower than that under normal and dry periods (Figure 2, Table 3), except at sites S5. At sites S1, S4, S6, S7, and S8, the water age is minimum under wet periods, and maximum under dry periods. At sites S2 and S3, the water age is minimum under wet periods, and maximum under normal periods. At site S5, the water age is maximum under wet periods, and minimum under dry periods.

The water age distribution under different water periods shows obvious spatial heterogeneity. Under wet periods, the small water age region takes up a large area of the small lake, but under dry periods, it is the opposite. Under wet periods (E1-N), the region of the water age fewer than 200 days occupies half of the small lake, almost all of the west part of the small lake, and the region of water age higher than 1400 days occupies mostly the northern of the small lake. Under normal periods (E2-N), the region of water age higher than 1400 days occupies mostly the east and south boundary and half of the northern part of the small lake, and the region of the water age fewer than 200 days occupies around one-third of the small lake. Under dry periods $(\mathrm{E} 3-\mathrm{N})$, the region of the water age fewer than 200 days occupies around one-sixth of the small lake, and the region of water age higher than 1400 is almost the same as that under normal periods (E2-N), except it is more in the southern part of the small lake (Figure 4).

The water age is mainly controlled by the inflow and outflow quantities. Increasing the quantities of the outflow and inflow can lower the water age. 


\subsection{Influences of Different Hydrological Connectivity Activities}

Increasing the hydraulic connectivity of the small lake by increasing the same amount of inflow and outflow can reduce the water age, especially near the position of the inlets and outlets. Under the dry periods, opening the ecological gate between the big lake and small lake allows the water from the east-west pumping station of the big lake to enter the small lake, meanwhile opening the Ahongkou gate outflow (E4) or increasing the Dawutizha gate outflow (equivalent to the outflow from Ahongkou gate) (E5) can reduce the water age of the eastern part and the south bank of the small lake (E4), or the region around the Dawutizha gate (E5) (Figure 4). The mean water age of the whole small lake under E4 and E5 is 550 and 598 days, which is lower than 794 under dry periods without adding more inflow and outflow (E3, Table 5). Besides, opening Ahongkou gate, the water age is almost the same as that under the wet periods, with the lowest value. Therefore, opening the ecological gate inflow between the big lake and small lake and the Ahongkou gate outflow is the favorable hydraulic connectivity to shorten the water age of the whole small lake. Adding other outflow positions reduces the water age of the small lake. The reasonable location of the inflow and outflow is important to reduce the water age.

The water ages of the sites S1, S2, S3, S4, and S5 (Figure 2) are almost the same between E4 and E5 (Tables 3 and 4), but the water ages of the sites S6 and S8 (Figure 2) under E4 are bigger than that under E5, and the water age of site S7 (Figure 2) under E4 is smaller than that under E5. These indicate, among the eight sites, that, only at one site, the water age under E5 is bigger than that under E4. It shows that the situation of the sites cannot represent that of the whole lake under different hydrological connectivity activities, and opening the Ahongkou gate can mostly reduce the water age of the southwestern part of the small lake.

\subsection{Influences of Wind Directions}

The northwestern wind can lower the water age of the small lake compared to the southwestern wind, the most common wind direction in this region. Comparing E3 and E6 in Figure 4, the different wind directions have influenced the water age of the small lake. The northwestern wind (E6-N) can low the water age of the northeastern corner, the maximum water age region, and the south boundary, and increase the water age of the southwestern corner of the small lake, compared to the southwestern wind (E3-N). The average water age of the whole lake is 757 days under northwestern wind (E6-N) which is smaller than that under southwestern wind (E3-N, 794 days, Table 5). The water age of the other sites, except sites S2, S3, and S7, under northwestern wind is lower than that under southwestern wind (Figure 2, Table 3). The southwestern wind may lower the water age of the sites (S2, S3, and S7 in Figure 2) along its direction, and the northwestern wind mostly influences the other sites.

\subsection{Influences of Point Farmland Drainages}

Comparing the six scenarios with and without farmland drainages, the average water age of the whole small lake without farmland drainages is larger than that with farmland drainages under wet and normal periods (E1, E2) and is lower than that with farmland drainages under dry periods (E3) (Table 5). Adding farmland drainages, among different scenarios, the mean water age of the whole small lake is the smallest one under wet periods (Table 5). Under wet and normal periods, the inflow and outflow of the small lake is high, and adding agriculture drainages results in increasing the inflow, so the water age of the small lake decreases. Under dry periods, the inflow and outflow of the small lake is low, and adding farmland drainages means increasing more trace concentration, and then the water age of the small lake increases. Similarly, if adding more inflow and outflow under dry periods, the average water age of the whole small lake with farmland drainages is higher than that without farmland drainages, even under northwestern wind (E3, E5, and E6 in Table 5). Increasing the water connectivity, the average water age of the whole small lake without farmland drainages is lower than that with farmland drainages (E4 and E5 in 
Table 5), which also means agriculture drainages bring more salt concentration. Without farmland drainages, the smallest average water age of the whole small lake is under E4 (Table 5), opening the Ahongkou gate and increasing inflow and outflow. The average water age of the whole small lake without farmland drainages is almost the same between that under the wet periods and adding the Dawutizha gate outflow (E1 and E5, in Table 5). With and without farmland drainages changed the water age rank between E1 and E4. With farmland drainages, E1 is the lowest one. Without farmland drainages, E4 is the lowest one.

In water age spatial distribution, adding farmland drainages at the northern part of the small lake, under wet and normal periods, the region with the water age more than 1600 days at the northern part was decreased, and in the center part with water age less than 200 days was also decreased; under dry periods, the water age of the northern region was decreased and that of the southwestern region was increased (Figures 4 and 5). Under dry periods, adding farmland drainages at the northern part of the small lake means increased inflow, the water age of the northern part was decreased, but more trace concentration flows into the small lake, so the water age of the southern part was increased.
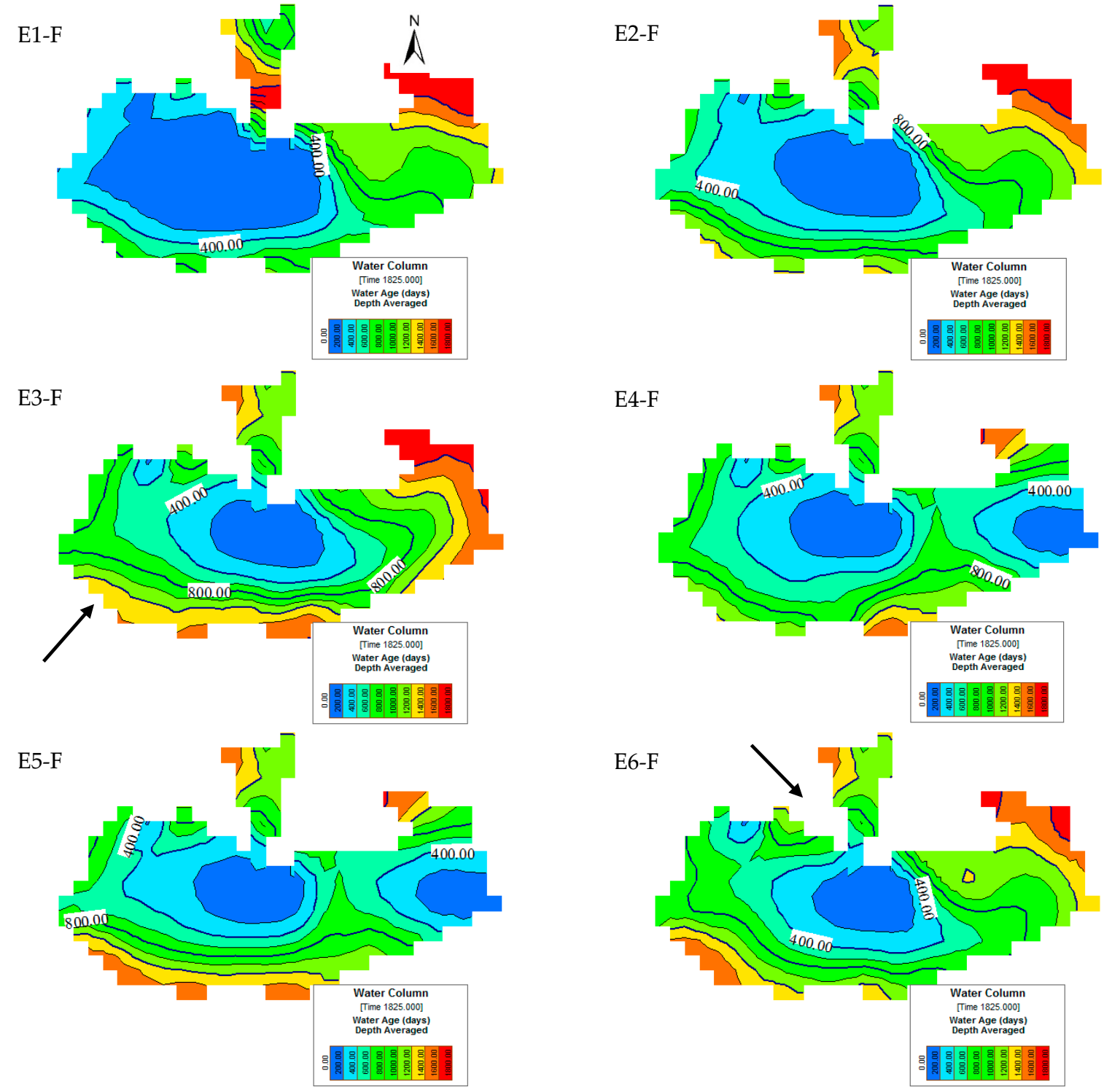

Figure 5. The water age distribution in the small lake under different scenarios after 5 years' simulation (considering farmland drainages, and the black arrows represent the schematic wind direction in the two comparing scenarios E3 and E6). 
Adding farmland drainages, the water age of the selected sites of the small lake increased mostly. Under wet, normal, and dry periods, the water age with farmland drainages at most sites is higher than that without farmland drainages (E1, E2, and E3 of Tables 3 and 4). However, the water age of sites S6 and S8 (Figure 2) with farmland drainages is lower than that without farmland drainages (Tables 3 and 5) under wet, normal, and dry periods, and the water age of sites S4 and S5 (Figure 2) with farmland drainages is lower than that without farmland drainages (Tables 3 and 4) under wet and normal periods. The water age of the whole lake and eight sites with and without farmland drainages varies differently under different scenarios.

\section{Discussion}

The water quality is associated with the water exchange and transport. Concepts of age are helpful for expressing the exchange and transport of water or substances in water bodies. Therefore, it is important that water age within the small lake is well understood. The increased water exchange and materials transport of a water body can usually be described by water age [5]. Water age is a crucial factor in exhibiting the degree of water exchange [31]. The concept of water age was employed to evaluate the transport timescales in response to water level fluctuation under variable constant flow rates in Dahuofang Reservoir [28]. Water age is identified to be the major parameter impacting the algal bloom dynamics in Xiangxi Bay after the impounding water of Three Gorges Reservoir; besides, a significant positive correlation has been found between the chlorophyll a (Chl-a) concentration in the surface layer and the water age of the dominant water source [10]. If the water age of a water body is large, contaminated water will be difficult to replace, and the contaminants will remain in a water body for ages.

A numerical simulation of the water age spatial variation of the small lake was carried out for the first time with EFDC. In comparison with bulk transport timescales, water age could reveal space and time heterogeneity $[15,68,69]$. It is worth knowing the spatial distribution of transport time, which could be used to reflect the influence of water hydrodynamics on biogeochemical processes and be applied for water environmental assessment. Moreover, the focus of transport timescales has transferred from global, or bulk timescales, such as flushing time, average residence time, and turnover time, to more detailed local timescales and their spatial variations [70]. Actually, in a lake, transport processes can change considerably in different regions, owing to the time-varying lake hydrodynamics. Our results show the water age of the small lake has considerable spatial variations. Similarly, water age in Lake Taihu has substantially spatial and temporal heterogeneity, with the average water age close to 130 days in summer and 230 days in other seasons during the simulation year [27].

The water age in the small lake is mainly controlled by the inflow and outflow quantities. This result is the same as the other following studies. Water age is a function of freshwater discharge in the tidal York River estuary, a western branch of the Chesapeake Bay [12]. Flow rate is one of the most important factors that impact water age in the Klamath River, California, North America [71]. There are appropriate inflow or outflow rates for water transfer projects to decrease the water age in Lake Taihu [27]. The vertical exchange time volume in summer is related to the total amount of river discharge, and the high vertical exchange time volume could be anticipated in the wet year in the Chesapeake Bay [72]. The water age during the high-flow periods was smaller than that during the low-flow periods in the Danshuei River estuarine system in northern Taiwan [26]. Water age distributions showed considerable spatial variation in the western part of the Strait of Johor, Malaysia for a range of inflow conditions [32]. The water age in Poyang Lake, the largest freshwater lake in China, is obviously affected by the hydrological conditions [69].

Wind direction affects water age. The northwestern wind can lower the water age of the small lake, compared to the southwestern wind. Similarly, southeastwardly wind, the dominant wind direction in summer, could decrease water age in eastern areas of Lake Taihu, which provide a drinking water source, and Meiliang Bay, the most polluted 
bay in the lake [27]. In the Chesapeake Bay, the short-term vertical exchange process is extremely controlled by the wind forcing, and the vertical exchange time volume decreases when the high-speed wind events are frequent [72]. Wind alters water age distribution in the tidal Rappahannock River, a western tributary of the Chesapeake Bay, USA [25]. The Patagonian fjord in Chile had high water age values due to increased wind stress [29]. Wind enhances transport and vertical mixing and changes the gravitational circulation in the water area [25].

The farmland drainage influences the water age of the small lake. It is the same as the results in a eutrophic shallow lake where nutrients and algal biomass were positively correlated to water age during a clean water donation; however, when the contributing system had high level of nutrients, aggregated nutrients in the lake might still cause lake eutrophication after a momentarily relief owing to flushing effect [73]. The water quality of the small lake can be lowered by decreasing the farmland drainages [33].

It is assumed that the lower the water age, the better the water environment. As a matter of fact, water age is not always reliable for evaluating water quality of a water body. Generally, transport time might trigger various fluctuations in water quality and dynamics of phytoplankton in water bodies. It is widely known that long water age can boost the eutrophication process by promoting nutrients uptake, transformation, and sink [74], and improving the growth and aggregation of algal biomass [75]. Larger water age suggests longer nutrient processing in the water bodies. More time taken inside the water bodies helps for increasing nutrient uptake by phytoplankton and the biogeochemical processes, for example nitrate reduction by denitrification [76-79]. In addition, in many rivers, lakes, and estuaries, nitrogen export and retention could be forecasted using water age $[79,80]$. Short transport time in theory diminishes accumulation of algal biomass and nutrients retention, therefore inhibiting eutrophication $[74,75,81,82]$. Water age revealed a similar spatial pattern with chlorophyll-a (Chl-a) in Poyang Lake [69], while it had a positive correlation with total phosphorus (TP), however was unrelated to total nitrogen (TN) and Chl-a in Lake Dianchi [5]. Furthermore, phytoplankton biomass may have a positive, negative, varying, or no significant relationship with transport time [4]. Considering the complex results, it is of necessity to further explore the relationship between transport time and water qualities, such as nutrients or phytoplankton biomass, in various water bodies.

\section{Conclusions}

The EFDC hydrodynamic model was applied to investigate the transport timescales in the small lake. From this diagnostic simulation, the distribution of water age of the small lake was investigated under different water periods, with and without agriculture drainages, and under northwestern and southwestern wind directions. The water age is lower under wet periods, and larger under dry periods. After five years' simulation, the average water age in the whole small lake system is 594, 684, and 794 days under wet, normal, and dry periods. The modeled water age in the small lake has high spatial variability, and its spatial difference changed under wet, normal, and dry periods. The worst water exchange circumstances were identified in the northeastern areas, and the best were in the center of the small lake. The spatial water age was mainly dominated by the varying inflow and outflow. Increasing the inflow and outflow of the small lake, the water age was decreased, especially near the positions of the inlet and outlet. Under dry periods, comparative analysis of the spatial water age distribution discovered that increasing the hydraulic connectivity of the small lake by opening the ecological gate between the small lake and big lake (letting the big lake outflow flow into the small lake) and Ahongkou gate of the small lake (increasing the outflow of the small lake and lowering the water age of most of the whole lake) can reduce the water age of the small lake, which is the more advantageous hydraulic conditions primarily ameliorating the water exchange in most regions of the small lake, and this way can be used in hydraulic engineering to improve its water age. The farmland drainages into the small lake should be controlled. The southwestern wind, the most common wind direction in this region, had a bad influence 
on the water age of the small lake, compared to the northwestern. The results of this study are helpful to better understand the water exchange and renewal process of the small lake and provide information for the local government and decisionmakers to protect the water environment of the small lake, such as increasing the inflow and outflow, and opening the ecological gate and Ahongkou gate of the small lake, etc.

Author Contributions: Writing—original draft preparation, Y.L.; writing—review and editing, R.Z.; supervision, A.B.; project administration, T.L. All authors have read and agreed to the published version of the manuscript.

Funding: This research was supported by the National Key Research and Development Program of China, grant number 2017YFC0404501, K.C. Wong Education Foundation, grant number GJTD2020-14, the Strategic Priority Research Program of Chinese Academy of Sciences, grant number XDA20060303, Tianshan Innovation Team Project of Xinjiang Department of Science and Technology, grant number Y744261, National Natural Science Foundation of China (NSFC), grant number 42071049 and 41101040, and "Western Light" Talents Training Program of CAS, grant number XBBS201005.

Acknowledgments: We appreciate all of the anonymous editors and reviewers for providing significant comments that helped improve this paper.

Conflicts of Interest: All authors declare that there are no conflict of interest.

\section{References}

1. Ho, J.C.; Michalak, A.M.; Pahlevan, N. Widespread global increase in intense lake phytoplankton blooms since the 1980s. Nature 2019, 574, 667-670. [CrossRef]

2. Sinha, E.; Michalak, A.M.; Balaji, V. Eutrophication will increase during the 21st century as a result of precipitation changes. Science 2017, 357, 405-408. [CrossRef]

3. Smith, V.H.; Schindler, D.W. Eutrophication science: Where do we go from here? Trends Ecol. Evol. 2009, 24, 201-207. [CrossRef]

4. Lucas, L.; Thompson, J.; Brown, L. Why are diverse relationships observed between phytoplankton biomass and transport time? Limnol. Oceanogr. 2009, 54, 381-390. [CrossRef]

5. Zhang, X.; Zou, R.; Wang, Y.; Liu, Y.; Zhao, L.; Zhu, X.; Guo, H. Is water age a reliable indicator for evaluating water quality effectiveness of water diversion projects in eutrophic lakes? J. Hydrol. 2016, 542, 281-291. [CrossRef]

6. Bolin, B.; Rodhe, H. A note on the concepts of age distribution and transit time in natural reservoirs. Tellus 1973, 25, 58-62. [CrossRef]

7. Takeoka, H. Fundamental concepts of exchange and transport time scales in a coastal sea. Cont. Shelf Res. 1984, 3 , 322-326. [CrossRef]

8. Deleersnijder, E.; Delhez, E.J.M. Timescale- and tracer-based methods for understanding the results of complex marine models (Editorial). Estuar. Coast. Shelf Sci. 2007, 74, 585-780. [CrossRef]

9. Wan, Y.; Qiu, C.; Doering, P.; Ashton, M.; Sun, D.; Coley, T. Modeling residence time with a three-dimensional hydrodynamic model: Linkage with chlorophyll a in a subtropical estuary. Ecol. Model. 2013, 268, 93-102. [CrossRef]

10. Gao, Q.; He, G.; Fang, H.; Bai, S.; Huang, L. Numerical simulation of water age and its potential effects on the water quality in Xiangxi Bay of Three Gorges Reservoir. J. Hydrol. 2018, 566, 484-499. [CrossRef]

11. Schlosser, P.; Bullister, J.L.; Fine, R.A.; Jenkins, W.J.; Key, R.; Lupton, J.; Roether, W.; Smethie, W.M., Jr. Transformation and age of water masses. In Ocean Circulation and Climate: Observing and Modelling the Global Ocean; Siedler, G., Church, J., Gould, J., Eds.; Academic Press: New York, NY, USA, 2001; pp. 431-452.

12. Shen, J.; Haas, L. Calculating age and residence time in the tidal York River using three-dimensional model experiments. Estuar. Coast. Shelf Sci. 2004, 61, 449-461. [CrossRef]

13. Gustafsson, K.E.; Bendtsen, J. Elucidating the dynamics and mixing agents of a shallow fjord through age tracer modeling. Estuar Coast. Shelf Sci. 2007, 74, 641-654. [CrossRef]

14. Zimmerman, J. Mixing and flushing of tidal embayments in the western Dutch Wadden Sea part I: Distribution of salinity and calculation of mixing time scales. Neth. J. Sea Res. 1976, 10, 149-191. [CrossRef]

15. Monsen, N.E.; Cloern, J.E.; Lucas, L.V.; Monismith, S.G. A comment on the use of flushing time, residence time, and age as transport time scales. Limnol. Oceanogr. 2002, 47, 1545-1553. [CrossRef]

16. Okada, T.; Nakayama, K.; Takao, T.; Furukawa, K. Influence of freshwater input and bay reclamation on long-term changes in seawater residence times in Tokyo bay, Japan. Hydrobiol. Process. 2011, 25, 2694-2702. [CrossRef]

17. Sheldon, J.E.; Alber, M. A comparison of residence time calculations using simple compartment models of the Altamaha River Estuary, Georgia. Estuaries Coasts 2002, 25, 1304-1317. [CrossRef]

18. Delhez, E.J.M.; Heemink, A.W.; Deleersnijder, E. Residence time in a semi-enclosed domain from the solution of an adjoint problem. Estuar. Coast. Shelf Sci. 2004, 61, 691-702. [CrossRef] 
19. Pilotti, M.; Simoncelli, S.; Valerio, G. A simple approach to the evaluation of the actual water renewal time of natural stratified lakes. Water Resour. Res. 2014, 50, 2830-2849. [CrossRef]

20. Viero, D.P.; Defina, A. Water age, exposure time, and local flushing time in semi-enclosed, tidal basins with negligible freshwater inflow. J. Mar. Syst. 2016, 156, 16-29. [CrossRef]

21. Huang, W.; Liu, X.; Chen, X.; Flannery, M.S. Estimating river flow effects on water ages by hydrodynamic modeling in little manatee river estuary, Florida, USA. Environ. Fluid Mech. 2010, 10, 197-211. [CrossRef]

22. Deleersnijder, E.; Campin, J.M.; Delhez, E.J.M. The concept of age in marine modelling: I. theory and preliminary model results. J. Mar. Syst. 2001, 28, 229-267. [CrossRef]

23. Delhez, E.J.M.; Campin, J.M.; Hirst, A.C.; Deleersnijder, E. Toward a general theory of the age in ocean modelling. Ocean Model. 1999, 1, 17-27. [CrossRef]

24. Shen, J.; Wang, H.V. Determining the age of water and long-term transport timescale of the Chesapeake Bay. Estuar. Coast. Shelf Sci. 2007, 74, 585-598. [CrossRef]

25. Gong, W.P.; Shen, J.; Hong, B. The influence of wind on the water age in the tidal Rappahannock River. Mar. Environ. Res. 2009, 68, 203-216. [CrossRef]

26. Liu, W.C.; Chen, W.B.; Hsu, M.H. Using a three-dimensional particle-tracking model to estimate the residence time and age of water in a tidal estuary. Comput. Geosci. UK 2011, 37, 1148-1161. [CrossRef]

27. Li, Y.; Tang, C.; Wang, C.; Tian, W.; Pan, B.; Hua, L.; Lau, J.; Yu, Z.B.; Achaya, K. Assessing and modeling impacts of different inter-basin water transfer routes on Lake Taihu and the Yangtze River, China. Ecol. Eng. 2013, 60, 399-413. [CrossRef]

28. Li, X.; Shen, Y. Numerical simulation of the impacts of water level variation on water age in Dahuofang reservoir. Front. Earth Sci. 2015, 9, 209-224. [CrossRef]

29. Pinilla, E.; Castillo, M.I.; Pérez-Santos, I.; Venegas, O.; Valle-Levinson, A. Water age variability in a patagonian fjord. J. Mar. Syst. 2020, 210, 103376. [CrossRef]

30. Li, Y.; Acharya, K.; Yu, Z. Modeling impacts of Yangtze River water transfer on water ages in Lake Taihu, China. Ecol. Eng. 2011, 37, 325-334. [CrossRef]

31. Liu, H.; Ding, Y.; Wang, H.; Zhang, J. Lattice Boltzmann method for the age concentration equation in shallow water. J. Comput. Phys. 2015, 299, 613-629. [CrossRef]

32. Kazemi, Z.; Hashim, N.B.; Aslani, H.; Mohamad, K.A. Influence of Freshwater Inflow on Water Age in the Western Part of Johor Strait, Malaysia. In Proceedings of the SEPKA 2014 Civil Engineering Research Seminar UTM Skudai, Universiti Teknologi Malaysia, Skudai, Johor, Malaysia, January 2014.

33. Liu, S. Model and forecast on the outlet water quality mineral of Bosten Lake's Xiaohu area. Oceanol. Et Limnol. Sin. 1996, $27,451-454$.

34. Xia, J.; Zuo, Q.T.; Shao, M.C. Sustainable Management of Water Resources in Lake Bosten; Chinese Science Press: Beijing, China, 2003.

35. $\mathrm{Hu}, \mathrm{R}$. Physical Geography of the Tianshan Mountaion in China; China Environment Science Press: Beijing, China, 2004.

36. Li, Y.A.; Tan, Y.; Jiang, F.Q.; Wang, Y.J.; Hu, R.J. Study on hydrological features of the Kaidu River and the Bosten Lake in the second half of 20th century. J. Glaciol. Geocryol. 2003, 25, 215-218.

37. Wang, Y.J.; Li, Y.A.; Wang, Y.G.; Tan, Y. Study on the change of inflow and salt content of the Bosten Lake, Xinjiang since the 1950s. Arid Zone Res. 2005, 22, 355-360.

38. Yuan, X.; Yang, D.H. Study on the Aqueous Environment Problems of the Bosten Lake, Xinjiang. Arid Zone Res. 2008, 25, 735-740.

39. Ran, X.J.; Shen, L.; Li, X.H. Analysis of Ecological Environment Effects in Bosten Lake. J. Water Resour. Water Eng. 2010, 21, 105-108.

40. Wei, K.Y.; Lee, M.Y.; Wang, C.H.; Wang, Y.; Lee, T.Q.; Yao, P. Stable isotopic variations in oxygen and hydrogen of waters in Lake Bosten region, Southern Xinjiang, Western China. West. Pac. Earth Sci. 2002, 2, 67-82.

41. Zhong, R.S.; Dong, X.G. Water-salt balance and water environment forecast of Lake Bosten in Xinjiang. J. Lake Sci. 2008, 20, 58-64.

42. Study on the Influence of the Location of Bosten Lake East Pumping Station on Lake Water Circulation and Water Quality. Special Report in Environmental Impact Assessment of the Construction of Bosten Lake East Pumping Station; The Institute of Environmental Science, Xi'an University of Technology: Xi'an, China, 2002.

43. Zuo, Q.T. Effect and Risk of Ecological Water Transportation from Bosten Lake to Tarim River. Sci. Geogr. Sin. 2006, 26, 564-568.

44. Xu, H.L.; Guo, Y.P.; Li, W.H. Analysis on the water pollution in Bosten Lake, Xinjiang. Arid Zone Res. 2003, 20, $192-196$.

45. Zuo, Q.T.; Dou, M.; Chen, X.; Zhou, K.F. Physically-based model for studying the salinization of Bosten Lake in China. Hydrol. Sci. J. 2006, 51, 432-449. [CrossRef]

46. Huang, X.; Chen, F.; Fan, Y.; Yang, M. Dry late-glacial and early Holocene climate in arid central Asia indicated by lithological and palynological evidence from Bosten Lake, China. Quat. Int. 2009, 194, 19-27. [CrossRef]

47. Xie, G.J.; Zhang, J.; Tang, X.M.; Cai, Y.; Gao, G. Spatio-temporal heterogeneity of water quality and succession patterns in Lake Bosten during the past 50 years. J. Lake Sci. 2011, 23, 988-998.

48. Zuo, Q.T.; Chen, X. Water Planning and Management Meeting Sustainable Development; China Hydropower Press: Beijing, China, 2003.

49. Wang, Y.; Li, X.; Li, H.; Ren, Y. Study on the changes of the small lake wetland in Bosten Lake and it's protective countermeasures. Trans. Oceanol. Limnol. 2010, 2, 123-129.

50. Zhang, J.P. Eco-environment Situation of Bosten Lake Basin and Its Countermeasures. Environ. Sci. Technol. 2010, 23, 76-79. 
51. Li, W.H.; Chen, Y.B.; Xu, H.L.; Guo, Y.P. A study on water environmental protection and sustainable utilization of Bosten Lake, Xinjiang. Geogr. Res. 2003, 22, 1-7.

52. Hamrick, J.M. User's Manual for the Environmental Fluid Dynamics Computer Code. Special Report No. 331 in Applied Marine Science and Ocean Engineering; Virginia Institute of Marine Science: Williamsburg, VA, USA, 1996.

53. Craig, P.M. User's Manual for EFDC_Explorer: A Pre/Post Processor tor the Environmental Fluid Dynamics Code; Dynamic SolutionsInternational, LLC: Edmonds, WA, USA, 2012.

54. Hamrick, J.M. A Three-Dimensional Environmental Fluid Dynamics Computer Code: Theoretical and Computational Aspects. Special Report No. 317 in Applied Marine Science and Ocean Engineering; Virginia Institute of Marine Science: Williamsburg, VA, USA, 1992.

55. Hamrick, J.M. The Environmental Fluid Dynamics Code: Theory and Computation. In Hydrodynamics and Mass Transport; Tetra Tech Inc.: Fairfax, VA, USA, 2007; Volume 1.

56. Park, K.; Kuo, A.; Shen, J.; Hamrick, J. A Three-Dimensional Hydrodynamic-Eutrophication Model (HEM-3D): Description of Water Quality and Sediment Process Submodels (EFDC Water Quality Model); Special Report No. 327 in Applied Marine Science and Ocean Engineering; Tetra Tech, Inc.: Fairfax, VA, USA, 2000.

57. Hamrick, J.; Wu, T. Computational Design and Optimization of the EFDC/HEM3D Surface Water Hydrodynamic and Eeutrophication Models. In Next Generation Environmental Models and Computational Methods; Delice, G., Vheeler, M.F., Eds.; Society of Industrial and Applied Mathematics: Philadelphia, PA, USA, 1997; pp. 143-161.

58. Ji, Z.G.; Morton, M.; Hamrick, J. Wetting and Drying Simulation of Estuarine Processes. Estuar. Coast. Shelf Sci. 2001, 53, 683-700. [CrossRef]

59. Wang, Y.; Jiang, Y.; Liao, W.; Gao, P.; Huang, X.; Wang, H.; Song, X.; Lei, X. 3-D hydro-environmental simulation of Miyun reservoir, Beijin. J. Hydro-Environ. Res. 2014, 8, 383-395. [CrossRef]

60. Mellor, G.L.; Yamada, T. Development of a turbulence closure model for geophysical fluid problems. Rev. Geophys. 1982, 20, 851-875. [CrossRef]

61. Galperin, B.; Kantha, L.H.; Hassid, S.; Rosati, A. A quasi-equilibrium turbulent energy model for geophysical flows. J. Atmos. Sci. 1988, 45, 55-62. [CrossRef]

62. Tetra Tech. The Environmental Fluid Dynamics Code Theory and Computation, Volume 3: Water Quality Module Technical Report to US EPA; Tetra Tech: Fairfax, VA, USA, 2007.

63. Liu, Y.; Bao, A.M. Exploring the effects of hydraulic connectivity scenarios on the spatial-temporal salinity changes in Bosten Lake through a model. Water 2020, 12, 40. [CrossRef]

64. HydroQual Inc. A Primer for ECOMSED, Version 1.3, User's Manual; HydroQual Inc.: Mahwah, NJ, USA, 2002.

65. Smagorinsky, J. General circulation experiments with the primitive equations: The basic experiment. Mon. Weather Rev. 1963, 91, 99-164. [CrossRef]

66. Berntsen, J. Internal pressure errors in sigma-coordinate ocean models. J. Atmos. Ocean. Technol. 2002, 19, 1403-1414. [CrossRef]

67. Hamrick, J.M. Application of the EFDC, Environmental Fluid Dynamics Computer Code to SFWMD. In Water Conservation Area 2A; South Florida Water Management District: West Palm Beach, FL, USA, 1994; pp. 1-126.

68. Liu, S.; Ye, Q.; Wu, S.; Stive, M.J.F. Wind effects on the water age in a large shallow lake. Water 2020, 12, 1246. [CrossRef]

69. Qi, H.; Lu, J.; Chen, X.; Sauvage, S.; Sanchez-P'erez, J.M. Water age prediction and its potential impacts on water quality using a hydrodynamic model for Poyang Lake, China. Environ. Sci. Pollut. Res. 2016, 23, 13327-13341. [CrossRef] [PubMed]

70. Oliveira, A.; Baptista, A.M. Diagnostic modeling of residence times in estuaries. Water Resour. Res. 1997, 33, 1935-1946. [CrossRef]

71. Javaheri, A.; Babbar-Sebens, M.; Alexander, J.; Bartholomew, J.; Hallett, S. Global sensitivity analysis of water age and temperature for informing salmonid disease management. J. Hydrol. 2018, 561, 89-97. [CrossRef]

72. Hong, B.; Shen, J. Linking dynamics of transport timescale and variations of hypoxia in the Chesapeake Bay. J. Geophys. Res. Oceans 2013, 118, 6017-6029. [CrossRef]

73. Tang, C.; He, C.; Li, Y.; Acharya, K. Diverse responses of hydrodynamics, nutrients and algal biomass to water diversion in a eutrophic shallow lake. J. Hydrol. 2021, 593, 125933. [CrossRef]

74. Bargu, S.; Justic, D.; White, J.R.; Lane, R.; Day, J.; Paerl, H.; Raynie, R. Mississippi River diversions and phytoplankton dynamics in deltaic Gulf of Mexico estuaries: A review. Estuar. Coast. Shelf Sci. 2019, 221, 39-52. [CrossRef]

75. Paerl, H.W.; Huisman, J. Blooms like it hot. Science 2008, 320, 57. [CrossRef]

76. Kaushal, S.S.; Groffman, P.M.; Mayer, P.M.; Striz, E.; Gold, A.J. Effects of stream restoration on denitrification in an urbanizing watershed. Ecol. Appl. 2008, 18, 789-804. [CrossRef] [PubMed]

77. Li, S.; Christensen, A.; Twilley, R.R. Benthic fluxes of dissolved oxygen and nutrients across hydrogeomorphic zones in a coastal deltaic floodplain within the Mississippi River delta plain. Biogeochemistry 2020, 149, 115-140. [CrossRef]

78. Klocker, C.A.; Kaushal, S.S.; Groffman, P.M.; Mayer, P.M.; Morgan, R.P. Nitrogen uptake and denitrification in restored and unrestored streams in urban Maryland, USA. Aquat. Sci. 2009, 71, 411-424. [CrossRef]

79. Dettmann, E.H. Coastal and estuarine research federation effect of water residence time on annual export and denitrification of nitrogen in estuaries: A model analysis. Estuaries 2001, 24, 481-490. [CrossRef]

80. Nixon, S.W.; Ammerman, J.W.; Atkinson, L.P.; Berounsky, V.M.; Billen, G.; Boicourt, W.C.; Boynton, W.R.; Church, T.M.; Elmgren, D.M.D.; Ai, E. The fate of nitrogen and phosphorus at the land-sea margin of the North Atlantic Ocean. Biogeochemistry 1996, 35, 141-180. [CrossRef] 
81. Janssen, A.B.G.; van Wijk, D.; van Gerven, L.P.A.; Bakker, E.S.; Brederveld, R.J.; DeAngelis, D.L.; Janse, J.H.; Mooij, W.M. Success of lake restoration depends on spatial aspects of nutrient loading and hydrology. Sci. Total Environ. 2019, 679, 248-259. [CrossRef]

82. Schmadel, N.M.; Harvey, J.W.; Alexander, R.B.; Schwarz, G.E.; Moore, R.B.; Eng, K.; Gomez-Velez, J.D.; Boyer, E.W.; Scott, D. Thresholds of lake and reservoir connectivity in river networks control nitrogen removal. Nat. Commun. 2018, 9, 1-10. [CrossRef] 